(REVIEW ARTICLE)

\title{
Improvement of smoked and fermented dried fish processing and application of essential oils as their natural preservatives.
}

\author{
Aymard Constantin Allagbé ${ }^{1}$, René Gnimabou Degnon ${ }^{1,}{ }^{*}$, Christian Tétédé Rodrigue Konfo 1, 2, Brice \\ Kpatinvoh ${ }^{1}$ and Baba-Moussa Farid ${ }^{3}$ \\ ${ }^{1}$ University of Abomey-Calavi, Polytechnic School of Abomey-Calavi, Laboratory of Study and Research in Applied \\ Chemistry, 01 PO Box: 2009 Cotonou, Benin. \\ ${ }^{2}$ National University of Agriculture (UNA), Schools of Science and Techniques for Preservation and Processing of \\ Agricultural Products (ESTCTPA), Food and Bioresources and Human Nutrition Science and Technology Laboratory, PO \\ Box114, Sakété, Benin. \\ ${ }^{3}$ Laboratory of Microbiology and Food Technology, Faculty of Science and Technology / University of Abomey-Calavi, \\ ISBA-Cotonou, Benin.
}

Publication history: Received on 07 May 2020; revised on 15 May 2020; accepted on 16 May 2020

Article DOI: https://doi.org/10.30574/wjarr.2020.6.2.0147

\begin{abstract}
A key factor limiting fish utilization is its extreme perishability due, especially, to microbial and autolytic spoilage during processing and storage. Thus, various traditional techniques are used to limit post-capture losses, in particular in West Africa where techniques such as drying, salting, smoking and fermentation are used individually or in combination for the conservation of fresh fish. Unfortunately, these techniques have long been handcrafted and influence the quality and shelf life of manufactured products. In other hand, recently the disappearance of many active synthetic substances in foods protection has resulted to a renewed interest in naturally occurring substances. In parallel to these disappearances, the regulatory environment incites strongly to increase the use of alternative methods to chemical control. In this review, we have summarized the innovations suggested in the literature for the improvement of fish processing techniques in order to ensure the manufactured product quality. Results show that several innovations have been proposed. This mainly concerns the invention of smoking and drying devices, the development of starters and the use of essential oils for fish preservation.
\end{abstract}

Keywords: Improvement; Fish processing; Essential oils; Preservation

\section{Introduction}

Hunger and malnutrition remain the major problems of our societies, in particular, populations in developing countries where the concept of food security remains a luxury. To contribute to the fight against food insecurity, we should increase agricultural production and promote the valorization local products through the judicious use of technical knowledge [1].

The agricultural sector has capital importance for the strengthening of the Beninese economy because it contributes $32.5 \%$ on average to the GDP, $75 \%$ to the export receipts, $15 \%$ to the receipts of the State and provides about $70 \%$ jobs. It is therefore considered to be the sector whose much potential must be judiciously exploited to support national economic growth and thus contribute to the effective fight against poverty [2]. Amon agricultural products are prominently products such as fish, milk and their respective derivatives.

Fish and fish products play a significant role in the diet of West African populations [3]. Fish is a foodstuff of high nutritional value but very perishable. It is also a valuable supplement in diets poor in proteins, vitamins and essential

* Corresponding author: René Gnimabou Degnon

Copyright (C) 2020 Author(s) retain the copyright of this article. This article is published under the terms of the Creative Commons Attribution Liscense 4.0. 
mineral salts. In Benin, fishing occupies a relatively important place in the national socio-economic balance because it supports around 500,000 people and contributes 3\% to the GDP [4]. However, the conservation of fish, particularly in hot countries, is difficult due to the lack of adequate conservation infrastructure and due to the climatic and environmental conditions which contribute to its degradation in a few hours [5]. In Benin, and like other countries in the western sub-region, post-harvest losses are estimated at around 20\% [5]. To limit these losses, smoking is one of the main methods of preserving fish and is still done in the traditional way [6]. For a few years, the safety of fish has been a public health problem, since pathogenic germs and / or chemical contaminants present in smoked fish have posed serious threats to the health of consumers [7]. Other concerns may arise from contamination of this commodity by molds, anaerobic sulfo-reducers and Staphylococci which, under certain conditions, can secrete toxins with hepatotoxic power $[8,9]$.

Chemical preservatives such as benzoates, sulphites, a-tocopherol, calcium chloride and citric acid were usually used for food preservation in general and especially drinks [6]. However, at short or long-term, these synthetic chemical products could be very toxic, with risks of mutagenicity, chromosomal aberrations and cancer [10, 11]. Due to the resurgence of the harmful effects of these chemical substances on the human health, the use of essential oils generally recognized as safe (GRAS) as bioconservatives agents of Fish and fish products could be a credible alternative. Indeed, essential oils possess antimicrobial activities and are without major effects on the environment and human health [12]. This article aims primarily to summarizing the research results on improvement of fish processing and application of plant extracts as essential oils for their conservation.

\section{Brief evidence on fish processing}

Fish processing definition may include various procedures like sorting, grading, gutting, deskinning, filleting, fermentation, drying and trimming. Furthermore, other processing procedures such as thermal processing (cooking, smoking etc.) can be applied to make product edible, to increase the price of the product on the market or to protect product against different spoilage and pathogen microorganisms [13]. In this study, we focused on improvement suggested for fish smoking, fermentation and drying (Table1).

\section{Description and manufacturing process of smoked fish}

\subsection{Description}

The smoking process has been used for hundreds of years either to preserve and extend the shelf-life of foods or to give them specific organoleptic characteristics (taste, flavour). In developed countries, fish smoking is applied by means of mechanical smokers [14]. Fish smoking process can be divided in two basic categories: cold smoking and hot smoking. The cold smoking processing is referred to the smoking of the product at a temperature up to $33{ }^{\circ} \mathrm{C}$. In this way, the intense thermal processing is avoided and nutrients' structure is preserved. As a consequence, cold smoking does not provide adequate protection against harmful microorganisms and further processing is required prior to consumption. The only exception to this rule is the smoked salmon, which is consumed raw. Hot smoking is referred to smoking of the product at a temperature that may reach up to $70-80^{\circ} \mathrm{C}$. The above process results in cooking of the fish thus making it suitable for direct consumption [15].

\subsection{Improvement of manufacturing process of smoked fish}

Depending on the type of fish, there are two smoking technologies. The first in which the fish is subjected to a large fire to reduce its moisture content before being subjected to smoke is used for lean fish such ensure a long shelf life ranging from 2 to 6 weeks. Regarding the second variant it is used for oily fish such as skate, catfish and others (Figure 1). The fish are subjected to the simultaneous action of smoke and fire for 2 to 6 hours of time depending on the species of fish. The shelf life of these is 2 to 3 days at most. To ensure their preservation and avoid putrefaction, processors heat up and package using cement paper and baskets every night after the market if all their stocks of smoked fat fish are not finished.

Several studies have investigated the influence of smoking on the quality of the fish and the possibilities for improving the process. According to Varlet et al [16], Phenolic compounds generated by the combustion combined with the temperature and the conditions of smoking can reduce the microbiological development and the oxidation. Products smoked by an indirect technique using external smoke generators have low polycyclic aromatic hydrocarbons and benzo[a]pyrene levels that are well below the maximum level of $5.0 \mathrm{mg} / \mathrm{kg}$ [17]. Roth et al [18] investigated the effectiveness of smoking on the quality preservation of stunned and pumped or live chilled of Atlantic salmon (Salmo salar). Fishes remained on ice during a period of 1 week and then were dry-salted $\left(18 \mathrm{~h}, 3-4{ }^{\circ} \mathrm{C}, \mathrm{pure} \mathrm{NaCl}\right)$ and smoked 
(Bastramat $\mathrm{C} 1500$, chamber temperature $1.4^{\circ} \mathrm{C}$, relative humidity $61 \pm 7 \%$, air velocity $0.5-1.0 \mathrm{~ms}-1$ ). A drying device invented by Dossou-yovo et al. [19] protects fermented fish from infestations. Fish dried by this device have a firmer texture without an aggressive odor and have a relatively low relative humidity (42.64\%) to be kept longer. According to Chabi et al. [20], traditional method of smoking exposes producers to smoking which has consequences on their health on 40 fish smokers. The results also revealed that smoked fish by improved furnace (Chorkor) are microbiological and nutritional better than smoked fish by traditional furnace.

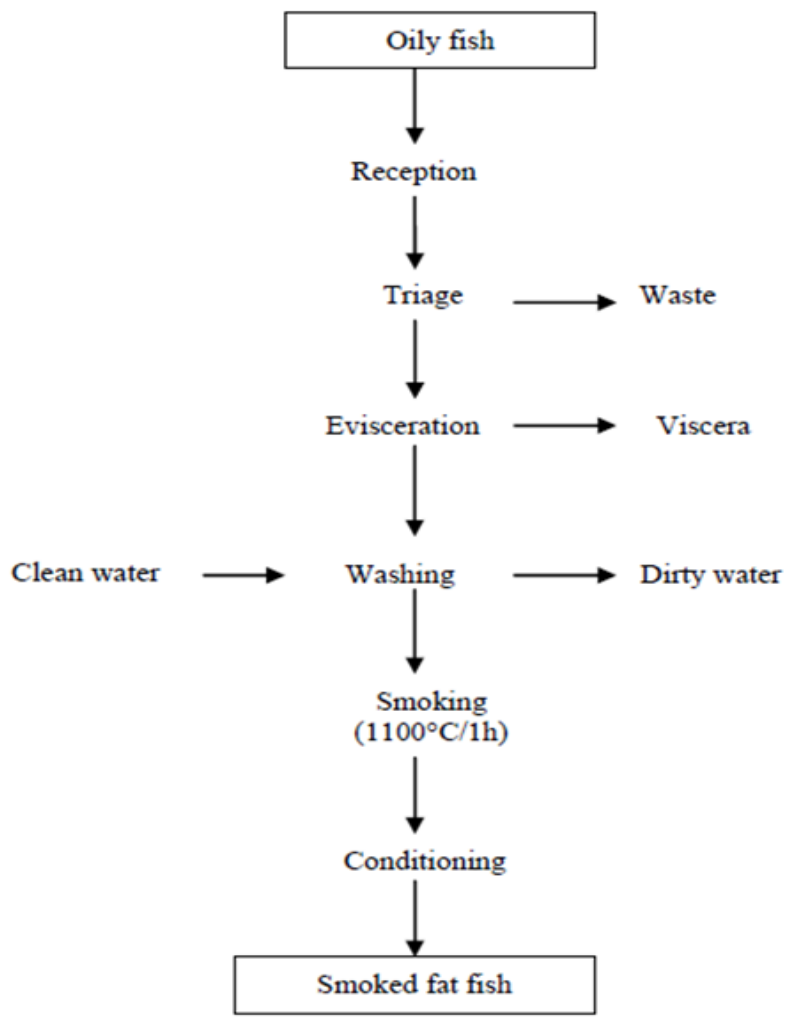

Figure 1 Manufacturing process of smoked fat fish [21].

\section{Definition and manufacturing process of lanhouin}

\subsection{Definition}

Lanhouin, a traditional fermented fish-based condiment is processed in the coastal areas of West African countries including Benin, Togo, Ghana, Nigeria and Côte-d'Ivoire. It is mostly used as taste enhancer and flavouring agent in many types of dishes [5, 22]. The raw materials used for Lanhouin production include the fish and the salt, and the fermentation is spontaneous and uncontrolled [23]. The product which is similar in color, taste and smell to that of other fermented fish products such as momone which retain their original texture is widely used as taste enhancer in many traditional dishes and low coast meat substitute [24].

\subsection{Improvement of manufacturing process of Ianhoin}

For traditional processing of lanhouin, the fish is scaled, gutted and sometimes cut into pieces and then left overnight at ambient temperature in fly free enclosure. The next day, the seemingly spoiled fish is washed. Dry salt is rubbed into gills, the belly cavity and on the surface. After this first salting, the fish is arranged in a basket, a can or a hole, covered with old cement paper bag and old clothes and allowed to ferment for 3 to 8 days at room temperature $\left(28\right.$ to $\left.30^{\circ} \mathrm{C}\right)$ before being removed, washed slightly and sun dried [5].

These last years, several works have brought improvements to lanhouin processing method. This work mainly suggested the improvement of processing equipment, the use of plant extracts such as essential oils for the control of microorganisms in lanhouin or the development of starters for its fermentation [24, 25, 26, 19]. Figure 2 shows improved lanhouin manufacturing process. 
Table 1 Summary of suggested improvements in fish processing

\begin{tabular}{|c|c|c|}
\hline Fish species investigated & Suggested improvement & References \\
\hline \multirow[t]{3}{*}{ Trachurus trachurus } & $\begin{array}{l}\text { Identification of potential sources of contamination and } \\
\text { suggestions for avoiding contamination. }\end{array}$ & {$[28]$} \\
\hline & $\begin{array}{l}\text { Use of clove essential oil (Syzigium aromaticum L.) in the } \\
\text { post-smoking preservation of mackerel. }\end{array}$ & {$[29]$} \\
\hline & $\begin{array}{l}\text { Use of Pimenta racemosa and Ocimum gratissimum in post- } \\
\text { smoking conservation. }\end{array}$ & {$[24]$} \\
\hline Ethmalosa fimbriata & Production of flours for their use as a dietary supplement & {$[30]$} \\
\hline \multirow[t]{2}{*}{ Galeoides decadactylus } & Fermentation and drying for its use as food supplement. & {$[31]$} \\
\hline & $\begin{array}{l}\text { Improvement of fermented fish flour quality using } \\
\text { essential oil extracted from Pimenta racemosa. }\end{array}$ & {$[25]$} \\
\hline 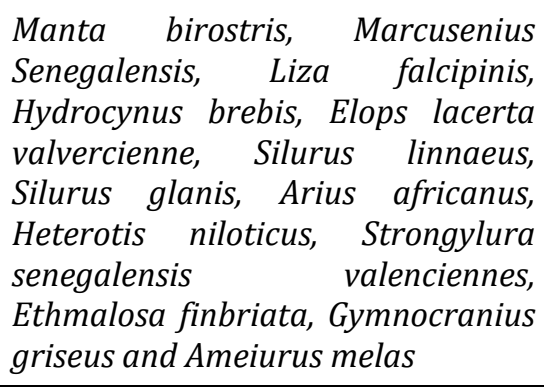 & $\begin{array}{l}\text { Evaluation of occurrence of Microbial Loads in Smoked } \\
\text { Fishes Marketed in the Lakeside Village of Guezin } \\
\text { (Southern Benin) to decrease associated microbiological } \\
\text { hazards. }\end{array}$ & {$[32]$} \\
\hline Caranx hippos & Use of ice-salt mixture for fish conservation. & {$[33]$} \\
\hline- & $\begin{array}{l}\text { Potential use of Cymbopogon citratus essential oil to } \\
\text { control Aspergillus Species from fermented fish products } \\
\text { of Southern Benin. }\end{array}$ & {$[26]$} \\
\hline $\begin{array}{l}\text { Manta birostris Liza falcipinis, } \\
\text { Silurus Linnaeus, Elops lacerta } \\
\text { valvercienne, (Arius africanus, } \\
\text { Ethmalosa finbriata, Ameiurus } \\
\text { melas,Oreochromis alcalia, Caranx } \\
\text { latus }\end{array}$ & $\begin{array}{l}\text { Evaluation of the Microbiological Quality of Smoked Fish } \\
\text { Taken at Lake Ahémé of Benin for risk control. }\end{array}$ & {$[21]$} \\
\hline Galeoides decadactylus & $\begin{array}{l}\text { Development of an improved device for drying fermented } \\
\text { fish called lanhouin in Benin. }\end{array}$ & [19] \\
\hline- & $\begin{array}{l}\text { Survey of the improvement of fish fermentation for } \\
\text { lanhouin production in Benin. }\end{array}$ & {$[34]$} \\
\hline- & $\begin{array}{l}\text { Use of Lactobacillus plantarum from fermented maize } \\
\text { dough hydrolysate to improve lanhouin }\end{array}$ & {$[27]$} \\
\hline- & $\begin{array}{l}\text { Construction of an improved smoking device (Chorkor } \\
\text { furnace) to improve the quality of smoked fish. }\end{array}$ & {$[20]$} \\
\hline $\begin{array}{l}\text { Scomber scombrus, } \\
\text { Trachurus trachurus }\end{array}$ & $\begin{array}{l}\text { Evaluation of the impact of break in cold chain on the } \\
\text { technological and organoleptic qualities. }\end{array}$ & {$[35]$} \\
\hline $\begin{array}{l}\text { Scomber scombrus } \\
\text { Trachurus Trachurus }\end{array}$ & $\begin{array}{l}\text { Improvement of technological quality and sensory by the } \\
\text { quality of smoking. }\end{array}$ & {$[36]$} \\
\hline Clarias gariepinus & $\begin{array}{l}\text { Optimization of the salt dose to preserve Biochemical } \\
\text { characteristics of fermented, Salty and Dried Catfish. }\end{array}$ & {$[37]$} \\
\hline- & $\begin{array}{l}\text { Use of cinderblock ovens as solutions for the sustainable } \\
\text { management of mangrove wood resources. }\end{array}$ & [19] \\
\hline
\end{tabular}




\begin{tabular}{|l|l|l|}
\hline Pseudotolithus $s p$ & $\begin{array}{l}\text { Identification of predominant organisms during naturally } \\
\text { fermented of cassava fish for lanhouin production for } \\
\text { improving fermentation. }\end{array}$ & $\begin{array}{l}\text { [38] } \\
\text { Pseudotolithus } s p \\
\text { Investigation on biochemical changes and aroma } \\
\text { development during the spontaneous fermentation of } \\
\text { Cassava fish into Lanhouin and their influence on product } \\
\text { acceptability. }\end{array}$ \\
\hline $\begin{array}{l}\text { Pseudotolithus } s p \\
\text { sp }\end{array}$ & $\begin{array}{l}\text { Use of starter cultures of Bacillus and Staphylococcus in } \\
\text { the controlled fermentation of Lanhouin. }\end{array}$ & [23] \\
\hline $\begin{array}{l}\text { Levelopment of a ferment for the artisanal production of } \\
\text { Lanhouin. -: Unspecified }\end{array}$ & {$[40]$} \\
\hline
\end{tabular}

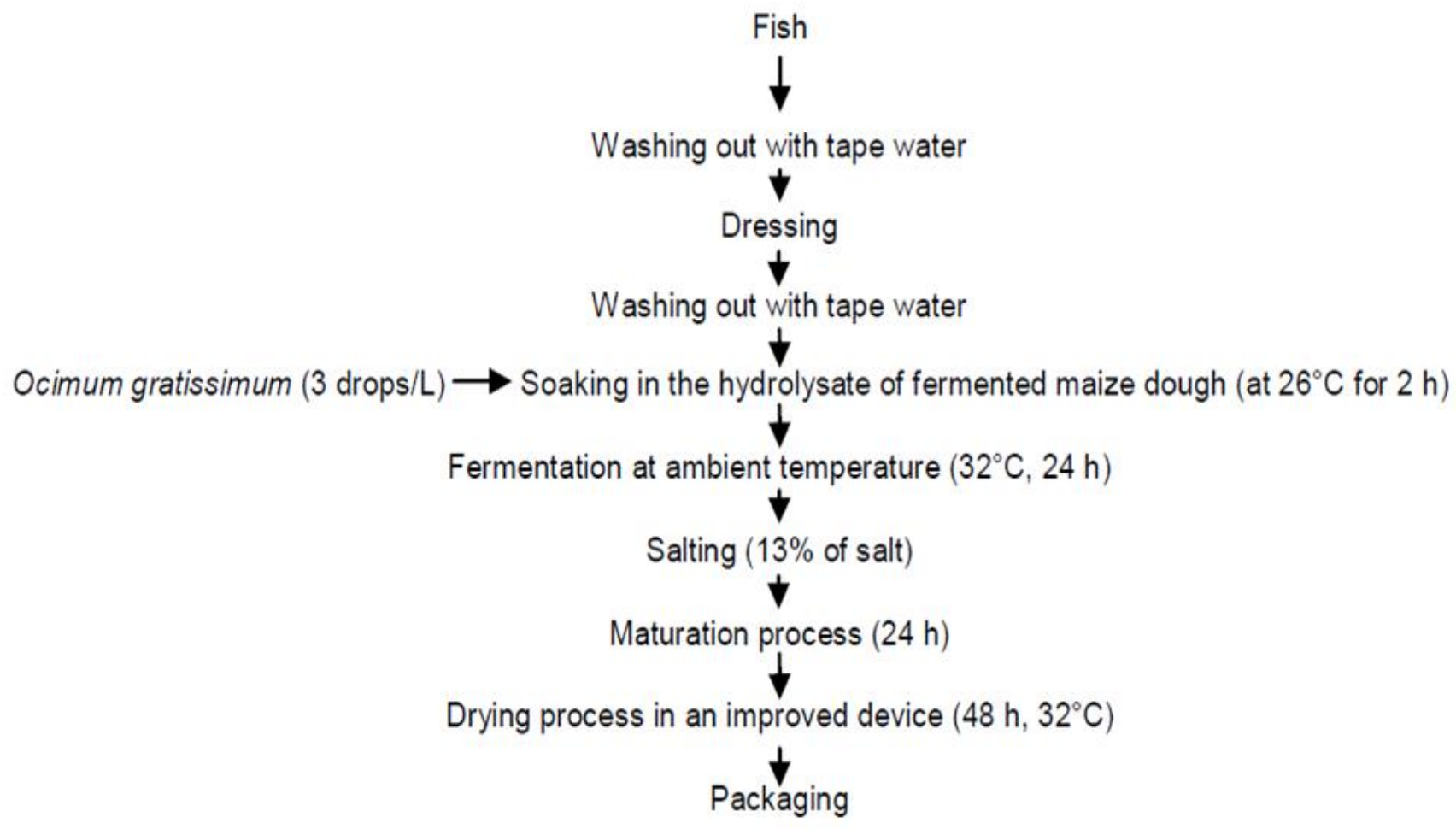

Figure 2 Flow chart of improved lanhouin production [27]

\section{Essential oils: their antimicrobial properties and potential applications in fish processing}

\subsection{Essential oils extraction and chemical analysis}

Essential oils are products, generally, of rather complex composition comprising the volatile principles contained in the plants, and more or less modified during the preparation process. They are essentially obtained by hydrodistillation where the plant material is heated in two to three times its weight of water with indirect steam from outside the still. Chemical analysis of essential oils is generally using GC (quantitative analysis) and GC/MS (qualitative analysis). Identification of the main components is carried out by the comparison of both the GC retention times and MS data against those of the reference standards (with known source) [41, 42]. 
Table 2 Major components and susceptible microorganisms to investigated essential oils.

\begin{tabular}{|c|c|c|c|c|}
\hline $\begin{array}{l}\text { Plant species } \\
\text { used }\end{array}$ & Countries & Identified Major components (\%) & Essential oil active against & References \\
\hline \multirow{2}{*}{$\begin{array}{l}\text { Syzigium } \\
\text { aromaticum }\end{array}$} & Benin & Eugenol (91.3), Trans- $\beta$-caryophyllene (4.4), eugenyl acetate (2.4) & A. candidus, P. camemberti & [29] \\
\hline & $\begin{array}{l}\text { Benin } \\
\text { Indonesia }\end{array}$ & $\begin{array}{l}\text { Eugenol }(60.4) \text {, Trans- } \beta \text {-caryophyllene }(24.0) \text {, eugenyl acetate }(10.0) \\
\text { eugenol }(70.43 \%), \beta \text {-caryophyllene }(16.79 \%), \alpha \text {-humulene }(3.05 \%) \text {, } \\
\text { caryophyllene oxide }(2.07 \%) \text {, tetratetracontane }(3.12 \%) \text {. }\end{array}$ & - & $\begin{array}{l}{[46]} \\
{[47]}\end{array}$ \\
\hline \multirow[t]{3}{*}{$\begin{array}{l}\text { Pimenta } \\
\text { racemosa }\end{array}$} & Benin & $\begin{array}{l}\text { Eugenol (51.1), Limonene (3.0), 1,8-cineole (2.7) } \\
\text { myrcene (25.1), chavicol (7.5) and eugenol (51.1). }\end{array}$ & A. candidus, P. camemberti & $\begin{array}{l}{[48]} \\
{[49]}\end{array}$ \\
\hline & Jamaica & Eugenol (45.60), Myrcene (24.97), Chavicol (9.31). & - & [48] \\
\hline & Spain & - & $\begin{array}{l}\text { K. pneumoniae, } S . \quad \text { marcescens, } S . \\
\text { thyphimurium, E. coli }\end{array}$ & [49] \\
\hline \multirow[t]{3}{*}{$\begin{array}{l}\text { Ocimum } \\
\text { gratissimum }\end{array}$} & Benin & $\begin{array}{l}\text { Thymol (26.9), } \gamma \text {-terpinene (20.0), p-cymene (17.6), } \alpha \text {-thujene (8.2), } \\
\text { myrcene (6.4). }\end{array}$ & $\begin{array}{l}\text { A. candidus, } P \text {. camemberti, E. coli, } S \text {. } \\
\text { aureus, } A \text {. niger, F. graminearum, } F \text {. } \\
\text { oxysporum, F. poae }\end{array}$ & {$[24,50]$} \\
\hline & Benin & Thymol (30), $\gamma$-Terpinene (27), p-Cymene $(16,4)$ & - & {$[51]$} \\
\hline & Kenya & $\begin{array}{l}\text { Eugenol (68.81), Methyl eugenol (13.21), cis-Ocimene (7.47), } \\
\text { Germacrene-D (4.25). }\end{array}$ & $\begin{array}{l}\text { S. aureus, K. pneumonia, P. mirabilis, } P \text {. } \\
\text { aeruginosae, E. coli, C. albicans, } \\
\text { Salmonella Enterica, Serovar Typhi }\end{array}$ & {$[52]$} \\
\hline \multirow[t]{4}{*}{$\begin{array}{l}\text { Cymbopogon } \\
\text { citratus }\end{array}$} & Benin & Geranial (41.3), neral (33.0), myrcene (10.4), and geraniol (6.6) & $\begin{array}{l}\text { A. ochraceus, A. oryzae, A. fumigatus, } A \text {. } \\
\text { parasiticus }\end{array}$ & {$[26]$} \\
\hline & & Myrcene (10.4), Neral $(33,0)$, Geranial (41.3). & $\begin{array}{l}\text { E. coli TCC 25922, S. aureus TCC25923, A. } \\
\text { niger, F. oxysporum, P. camembertii }\end{array}$ & {$[42]$} \\
\hline & Togo & Neral (31.36\%), Geranial (43.15), Myrcene (10.65\%). & $\begin{array}{l}\text { C. albicans, } C \text {. neoformans, } M \text {. } \\
\text { pachydermatis, } A \text {. fumigatus, } P \text {. } \\
\text { aeruginosa V5667, S. intermedius IP81.60 }\end{array}$ & {$[53]$} \\
\hline & Cameroon & E-Citral/Geranial (37.7); Z-Citral/Neral (21.2-80). & $\begin{array}{l}\text { Penicillium expansum, P. verrucosum, } A \text {. } \\
\text { ochraceus, A. flavus, L. monocytogenes, } \\
\text { Salmonella }\end{array}$ & {$[54]$} \\
\hline
\end{tabular}




\subsection{Antimicrobial activity of essential oils in fish systems}

Several studies have evaluated the chemical composition of essential oils as well as their antimicrobial power (Table 2). Spices and herbs can be used as an alternative preservative and pathogen-control method in food materials. Indeed, according to studies by Burt [43], essential oil of Mentha piperita had been recognized as bio preservatives for fish dishes and vegetables. Mint oil in the high fat products pâte' and fish roe salad exhibited little antibacterial effect against L. monocytogenes and S. enteritidis, whereas in cucumber and yoghurt salad (low fat) the same essential oil was much more effective. The spreading of essential oils on the surface of whole fish or using essential oils in a coating for shrimps appears effective in inhibiting the respective natural spoil [44]. According to Degnon et al. [29] the microbial flora associated with smoked fish are coliforms, staphylococci and molds such as Penicillium camemberti and Aspergillus candidus, which is relation to the low level of hygiene applied in the production of that food. In vitro antimicrobial tests indicated that essential oil of Syzygium aromaticum has a pronounced antimicrobial activity against spoilage flora. The preservation of smoked fish by incorporation essential oil increased the shelf life of the product. However, this protection is not for a long time due to the volatile property of the essential oil.

Antifungal agents such as essential oils kill the fungal cell via binding primarily to ergosterol, the major sterol found in fungal cellular membrane. This binding destroys the osmotic integrity of the membrane, and this is followed by leakage of intracellular potassium, magnesium, sugars, and metabolites and finally by cellular death. Lipid characteristics of essential oils act via the same mechanism. It has been suggested that oxidative damage due to essential oil may also contribute to its antifungal activity against Candida [42, 45].

\section{Perspectives for research}

In the near future, it would be interesting with regard to the fermented salted and dried lanhouin fish to evaluate the cumulative effectiveness of the starters developed, the essential oils investigated as well as the invented improved drying devices. It could be also important to test the cumulative effect of improved funace such as the chokor oven and essential oils. Finally, it will be necessary to assess the acceptability of the improved finished products at the consumer level.

\section{Conclusion}

Several artisanal treatments reduce post-capture losses of fish. However, nowadays, the smoking and fermentation of fish became one of the mostly conservation methods. Despite the social importance and the nutritious nature of smoking and fermented fish, several problems are remained related to their hygienic quality as well as their suitability for conservations. In this review we highlighted the improvements suggested in recent years to the smoking and fish fermentation processes in Africa. The results show that several innovations have been proposed. This mainly concerns the invention of smoking and drying devices, the development of starters and the use of aromatic plant extracts in the conservation of fish. However, it would be interesting to assess the cumulative effectiveness of its innovations.

\section{Compliance with ethical standards}

\section{Acknowledgments}

The authors sincerely thank all the research teams of the Faculties of Agronomic Sciences and Sciences and Techniques of the University of Abomey-Calavi for their invaluable contribution in the improvement of fish processing technologies in Benin.

\section{Disclosure of conflict of interest}

The authors agree no conflict of interest.

\section{References}

[1] Konfo C, Ahoussi-Dahouénon E, Sessou P, Yehouenou B, Djenontin S, De Souza C and Sohounhloué D. (2012). Stabilization of local drink" Tchakpalo" produced in Benin by addition of essential oil extracted from fresh leaves of Cymbopogon citratus. International Research Journal of Biological Sciences, 1(8), 40-49. 
[2] FAO et Commission de la CEDEAO. (2018). Profil National Genre des Secteurs de l'Agriculture et du Developpement Rural - Bénin. Serie des Évaluations Genre des Pays. Cotonou, 148.

[3] FAO. (2000). United Nations Food and Agriculture Organization. FAO yearbook. Fishery statistics capture production, 86(1), 99- 100.

[4] Tossou S. (2010). Rapport national d'évaluation de l'application des mesures sanitaires et phytosanitaires dans la commercialisation des produits de la pêche au Bénin, 8.

[5] Anihouvi VB, Hounhouigan JD and Ayernor GS. (2005). La production et la commercialisation du Lanhouin, un condiment à base de poisson fermenté du Golfe du Bénin. Cahiers Agricultures, 14(3), 23-330.

[6] Anoh KP. (1998). Contribution à l'étude du réseau de distribution des ressources halieutiques marines en Côte d'Ivoire. Thèse 3eme cycle : géographie : Université de Côte d'Ivoire, faculté des arts et sciences humaines, Département de géographie, p. 323.

[7] Tongo I, Ogbeide 0 and Ezemonye L. (2017). Human health risk assessment of polycyclic aromatic hydrocarbons (PAHs) in smoked fish species from markets in Southern Nigeria. Toxicology reports, 4, 55-61.

[8] Gallot $S$ and Fremy JM. (2006). Evaluation des risques liés à la présence des mycotoxines dans les chaines alimentaires humaines et animales. Rapport synthétique AFSSA, Paris, 25.

[9] AFSSA. (2009). Évaluation des risques liés à la présence de mycotoxines dans les chaînes alimentaires humaine et animale. Rapport final de Mars, 308.

[10] Tfouni SAV and Toledo MCF. (2002). Estimates of the Mean per Capital Daily Intake of Benzoic and Sorbic Acids in Brazil, Food Addit. Cont, 19, 647-654.

[11] Jatto WO and Adegoke GO. (2010). Storage studies on cashew juice preserved with water extracted Aframomum danielli Electr. J. Environ. Agric. Food Chem, 9, 1351-1359.

[12] Sessou Philippe, Souaïbou F, Paulin A, Issaka Y and Dominique S. (2012). In vitro Antifungal activities of Essential oils extracted from Fresh Leaves of Cinnamomum zeylanicum and Ocimum gratissimum against Foodborne pathogens for their use as Traditional Cheese Wagashi conservatives. Research Journal of Recent Sciences, 1(9), 67-73.

[13] Thrane M, Nielsen EH and Christensen P. (2009). Cleaner production in Danish fish processing-experiences, status and possible future strategies. Journal of cleaner Production, 17(3), 380-390.

[14] Arvanitoyannis IS and Kotsanopoulos KV. (2012). Smoking of fish and seafood: history, methods and effects on physical, nutritional and microbiological properties. Food and bioprocess technology, 5(3), 831-853.

[15] Bannerman AMcK. (1980). Hot smoking of fish. Torry research advisory note \#82. Torry Research Station. Aberdeen: Ministry of Agriculture, Fisheries and Food.

[16] Varlet V, Serot T, Monteau F, Bizec BL and Prost C. (2007). Determination of PAH profiles by GC-MS/MS in salmon processed by four cold-smoking techniques. Food additives and contaminants, 24(7), 744-757.

[17] Wretling S, Eriksson A, Eskhult GA and Larsson B. (2010). Polycyclic aromatic hydrocarbons (PAHs) in Swedish smoked meat and fish. Journal of food composition and analysis, 23(3), 264-272.

[18] Roth B, Birkeland S and Oyarzum F. (2009). Stunning, pre slaughter and filleting conditions of Atlantic salmon and subsequent effect on flesh quality on fresh and smoked fillets. Aquaculture, 289, 350-356.

[19] Dossou-Yovo P, Bokosssa I, Ahouandjinou H, Zolotokopova S and Alaguina I. (2010). Performance d'un dispositif amélioré de séchage de poisson fermenté appelé lanhouin au Bénin. International Journal of Biological and Chemical Sciences, 4(6).

[20] Chabi NW, Konfo CT, Emonde PD, Chichi MTC, Sika KJC, Alamou Y and Baba-Moussa LS. (2014). Performance of an improved smoking device (Chorkor furnace) on the quality of smoked fish in the municipality of Aplahoue (Southeast Benin). International Journal of Innovation and Applied Studies, 9(3), 1383.

[21] Atrevy B, Degnon GR, Gbaguidi M, Akotowanou O, Gangbe M, Adjou SE, Kpatinvoh B and Dahouenon-Ahoussi E. (2019). Evaluation of the Microbiological Quality of Smoked Fish Taken at Lake Ahémé of Benin. Elixir Aquaculture 136, 53889-53893.

[22] Kindossi JM, Anihouvi VB, Vieira-Dalodé G, Akissoé NH, Jacobs A, Dlamini N and Hounhouigan DJ. (2012). Production, consumption, and quality attributes of Lanhouin, a fish-based condiment from West Africa. Food Chain, 2(1), 117-130. 
[23] Anihouvi VB, Toudonou HJ, Akissoe NH and Hounhouigan JD. (2012a). Essai de mise au point d'un ferment pour la production artisanale du Lanhouin, un condiment à base de poisson fermenté au Bénin. Bull Recherche Agron Bénin (BRAB), 72(11).

[24] Degnon RG, Faton AN, Adjou ES, Tchobo FP, Dahouenon-ahoussi E, Soumanou MM and Sohounhloue DC. (2013c). Efficacité comparée des huiles essentielles de deux plantes aromatiques dans la conservation post-fumage du Chinchard (Trachurus trachurus). Journal of Animal \&Plant Sciences, 19(1), 2831-2839.

[25] Adjou ES, Dègnon RG, Dahouenon-Ahoussi E, Soumanou MM and Sohounhloue DC. (2017). Improvement of fermented fish flour quality using essential oil extracted from fresh leaves of Pimenta racemosa (Mill.) JW Moore. Natural products and bioprospecting, 7(4), 299-305.

[26] Dègnon RG, Allagbé AC, Adjou ES and Dahouenon-Ahoussi E. (2019b). Antifungal Activities of Cymbopogon citratus Essential Oil against Aspergillus Species Isolated from Fermented Fish Products of Southern Benin. Journal of food quality and hazards control, 6, 53-57.

[27] Dossou-Yovo P, Bokossa I, Soprounova O, Eremeeva S and Yelouassi CAR. (2012). Survey of the presence of Lactobacillus plantarum in the fermented maize dough hydrolysate used in the technology of the improvement of lanhouin. African Journal of Microbiology Research, 6(23), 5074-5076.

[28] Degnon RG, Agossou VE, Adjou ES, Dahouenon-Ahoussi E, Soumanou MM and Sohounhloue DC. (2013a). Évaluation de la qualité microbiologique du chinchard (Trachurus trachurus) au cours du processus de fumage traditionnel. Journal of Applied Biosciences, 67, 5210-5218.

[29] Degnon GR, Faton AN, Adjou ES, Noudogbessi JP, Dahouenon-Ahoussi E, Soumanou MM and Sohounhloue DCK. (2013b). Antifungal potential of Clove essential oil (Syzigium aromaticum L.) in the post-smoking preservation of mackerel (Trachurus trachurus) in Benin. International Research Journal of Biological Sciences, 2(10), 36-42.

[30] Dègnon RG, Adjou ES, Ahouannou C, Dahouenon-Ahoussi E, Soumanou MM and Sohounhloué DC. (2013d). Evaluation of the microbiological and nutritional quality of two types of fish flours from Ethmalosa fimbriata for their use as a dietary supplement. International Journal of Biosciences, 3, 28-34.

[31] Dègnon RG, Adjou ES, Dahouenon-Ahoussi E, Soumanou MM and Fiogbé E. (2014). Evaluation of the Microbiological and Nutritional Quality of Fermented-Dried Lesser African Threadfin (Galeoides decadactylus) Used as Food Supplement in Southern Benin. Journal of Water Resource and Protection.

[32] Dègnon RG, Atrevy B, Adjou ES, Ahoussi E and Soumanou MM. (2018). Occurrence of Microbial Loads in Smoked Fishes Marketed in the Lakeside Village of Guezin (Southern Benin) and Associated Microbiological Hazards. American Journal of Microbiological Research, 6(5), 187-190.

[33] Degnon GR, Konfo TC, Adjou SE, Amidou OEN and Dahouenon-Ahoussi E. (2019a). Efficiency of the ice-salt mixture in the conservation of trevallies (Caranx hippos) caught at the artisanal fishing port of Cotonou (Southern Benin). International Journal of Biosciences, 14(5), 41-47.

[34] Dossou-yovo P, DY Roger, JG Innocent B and Iraïda P. (2011). Survey of the improvement of fish fermentation for lanhouin production in Benin. African Journal of Food Science, 5(17), 878-883.

[35] Assogba MHM, Salifou CFA, Tobada P, Aboudou AK, Bakary AB, Dahouda M and Karim IYA. (2020). Impact of break in cold chain on the Technological and organoleptic qualities of atlantic mackerel (scomber scombrus) and horse mackerel (trachurus trachurus) in south Benin. Journal of Microbiology, Biotechnology and Food Sciences, $9(4), 1242-1248$.

[36] Assogba MHM, Salifou CFA, Ahounou SG, Silemehou JAS, Dahouda M, Chikou A and Youssao AKI. (2018). Effet de la Fumaison sur les Qualités Technologiques et Sensorielles de Scomber Scombrus (Maquereau Commun) et de Trachurus trachurus (Chinchard) à Wlacodji dans le Sud du Bénin. International Journal of Progressive Sciences and Technologies, 9(1), 34-35.

[37] Yelouassi CAR, Dossou-Yovo P, Jacquet N and Richel A. (2018). Influence of Salt on the Biochemical Characteristics of Fermented, Salty and Dried Catfish (Clarias gariepinus) in Benin. Science, 6(6), 115-122.

[38] Anihouvi VB, Sakyi-Dawson E, Ayernor GS and Hounhouigan JD. (2007). Microbiological changes in naturally fermented cassava fish (Pseudotolithus sp.) for lanhouin production. International journal of food microbiology, 116(2), 287-291. 
[39] Anihouvi VB, Sakyi-Dawson E, Ayernor GS and Hounhouigan JD. (2009). Biochemical changes and aroma development during the spontaneous fermentation of cassava fish into lanhouin and their influence on product acceptability. Journal of Aquatic Food Product Technology, 18(4), 370-384.

[40] Anihouvi VB, Kpoclou EY and Hounhouigan JD. (201b2). Use of starter cultures of Bacillus and Staphylococcus in the controlled fermentation of Lanhouin, a traditional fish-based condiment from West Africa. African Journal of Microbiology Research, 6(22), 4767-4774.

[41] Sessou P, Farougou S and Sohounhloué D. (2012b). Major component and potential applications of plant essentials oils as natural food preservatives: a short review research results. International Journal of Biosciences, $2(2), 8$.

[42] Konfo CTR, Chabi NW, Dahouenon-Ahoussi E, Cakpo-Chichi M, Soumanou MM and Sohounhloue DCK. (2015). Improvement of African traditional sorghum beers quality and potential applications of plants extracts for their stabilization: a review. The Journal of Microbiology, Biotechnology and Food Sciences, 5(2), 190.

[43] Burt S. (2004). Essential oils:. their antibacterial properties and potential application in foods, A review, Int. J. Food Microbiol, 94, 223-253.

[44] Harpaz S, Glatman L, Drabkin V and Gelman A. (2003). Effects of herbal essential oils used to extend the shelf life of freshwater-reared Asian sea bass fish (Lates calcarifer). Journal of Food Protection, 66(3), 410-417.

[45] Murray R, Patrick baron JE, Jorgensen JH and Pfaller YRH. (2003). Manual of Clinical Microbiology 8è Ed, 18591879.

[46] Houinsou RF, Adjou ES, Ahoussi ED, Souhouhloué DCK and Soumanou MM. (2014). Biochemical and sensorial charactéristics of cowpea (vignaunguiculata) stored with essentials oils extracted from plant of Myrtaceaefamily. International journal of Innovation and Applied Studies, 9, 428-37.

[47] Wael S, Nuringtyas TR, Wijayanti N and Astuti P. (2018). Secondary Metabolites Production in Clove (Syzygium aromaticum): Chemical Compounds. Journal of Biological Sciences, 18(7), 399-406.

[48] Jirovetz L, Buchbauer G, Stoilova I, Krastanov A, Stoyanova A and Schmidt E. (2007). Spice plants: Chemical composition and antioxidant properties of Pimenta Lindl. essential oils, part 2: Pimenta racemosa (Mill.) JW Moore leaf oil from Jamaica. NUTRITION-VIENNA-, 31(7/8), 293.

[49] Houinsou RDL, Ahoussi E, Sessou P, Yèhouénou B and Sohounhloué D. (2012). Antimicrobial activities of essential oil extracted from leaves of ocimum gratissimum L. against pathogenic and adulterated microorganisms associated to tomato in Benin. International Journal of Biosciences (IJB), 2(11), 90-100.

[50] Saenz MT, Tornos MP, Alvarez A, Fernandez MA and Garcia MD. (2004). Antibacterial activity of essential oils of Pimenta racemosa var. terebinthina and Pimenta racemosa var. grisea. Fitoterapia, 75(6), 599-602.

[51] Yayi E, Gbenou JD, Ahoussi LA, Moudachirou M and Chalchat JC. (2004). Ocimum. gratissimum L., siège de variations chimiques complexes au cours du développement. Comptes Rendus Chimie, 7(10-11), 1013-1018.

[52] Matasyoh LG, Matasyoh JC, Wachira FN, Kinyua MG, Muigai AWT and Mukiama TK. (2007). Chemical composition and antimicrobial activity of the essential oil of Ocimum gratissimum L. growing in Eastern Kenya. African journal of biotechnology, 6(6).

[53] Koba KS, Raynaud C, Mandin D, Millet J and Chaumont JP. (2003). Activité antimicrobienne des huiles essentielles de Cymbopogon citratus L. (DC) Stapf., C. nardus L. Rendle et C. schoenanthus L. Spreng, Journal de Mycologie Médicale 13, 231-238.

[54] Nguefack J, Dongmo JL, Dakole CD, Leth V, Vismer HF, Torp J and Zollo PA. (2009). Food preservative potential of essential oils and fractions from Cymbopogon citratus, Ocimum gratissimum and Thymus vulgaris against mycotoxigenic fungi. International journal of food microbiology, 131(2-3), 151-156.

\section{How to cite this article}

Allagbé CA, Degnon RG, Konfo TRC, Kpatinvoh B and Baba-Moussa F. (2020). Improvement of smoked and fermented dried fish processing and application of essential oils as their natural preservatives. World Journal of Advanced Research and Reviews, 6(2), 129-138. 